\title{
Relationship between RMB to U.S Dollar Exchange Rate and Prices of US Textile Exports from China
}

\author{
Amina Kabirou ${ }^{1} \&$ Yongqiang Gao ${ }^{1}$ \\ ${ }^{1}$ School of Management, Huazhong University of Science and Technology, China \\ Correspondence: Amina Kabirou, School of Management, Huazhong University of Science and Technology, \\ China. E-mail: mikafric2000@yahoo.fr
}

Received: December 3, 2013

Accepted: December 19, 2013

Online Published: February 21, 2014

doi:10.5539/ijbm.v9n3p179

URL: http://dx.doi.org/10.5539/ijbm.v9n3p179

\begin{abstract}
China is the United States' second largest trading partner, with trade between the two countries rising from $\$ 5$ billion in 1981 to $\$ 536$ billion in 2012. However, the two countries are involved a trade dispute regarding China's refusal to appreciate the RMB. The undervaluation of RMB has affected US manufacturing firms especially in the textile industry. China exports textiles to the US at lower prices than US textiles in the domestic market. This has led to shutdown of US textile firms and job losses in the sector. China has a competitive advantage over the US in the textile industry because of cheap labor, economies of scope and scale and abundant labor supply. The US argues that if China allows RMB to appreciate, this will mean that the prices of Chinese exports to the US will rise. This will reduce the US China trade deficit. The appreciation of RMB to US dollar will increase the prices of US Textile exports to the US. The purpose of the paper is to analyze the relationship between RMB to the US Dollar and prices of US Textile exports.
\end{abstract}

Keywords: exchange rates, RMB nominal exchange rate, export pricing

\section{Introduction}

The rising trade disputes between the US and China, especially in relation to the Textiles industry, stem from the value of the Chinese Renminbi (RMB) to the US dollar. China continues refusing to appreciate its currency and does not use a floating exchange rate. This has affected the US Textile Industry with the US textile firms closing down, which has led to huge job losses in the sector. The relationship between RMB and the US dollar has resulted in higher prices of the US Textile exports to China and cheaper textile imports from China to the US. The undervalued RMB allows China to export textiles with very low prices. China has a great competitive advantage over the US in the textile industry because of its cheap labor costs. China has an abundant labor supply compared to the US, which makes its textile exports much cheaper than those produced in the US. The expiry of the Multi-Fiber Arrangement (MFA) in 2005 led to the rapid expansion of Chinese textiles. In addition, China's foreign exchange policy has led to the country's huge hold of US Treasury securities which stand at $\$ 1.3$ trillion in 2013. On the whole, the US has a huge trade deficit with China.

\section{The US-China Trade}

According to economic theories, when a country opens its borders to trade, it and its trading partners profit since they export goods that they produce efficiently and import goods that they 'do not. In accordance with the Ricardian theory of Comparative Advantage, nations will focus on and export the goods that they produce comparatively more efficiently than another country. This comparative efficiency, based on the Heckscher-Ohlin Theorem, is determined by a nation's endowments of job and capital. If a nation has a considerable supply of one factor, the price of using that factor is relatively low. In opposition, if a nation has a lacking supply of a factor, then the price of utilizing that factor will be higher. Therefore, the nation will focus on production and export the goods that most hugely use its abundant factor (Krugman, 2008).

China is the second largest trading partner of the United States as well as its biggest source of imports. The total US-China trade was US $\$ 5$ billion compared to US $\$ 536$ billion in 2012 . The huge bilateral trade is beneficial to both countries. Many US firms have invested heavily in China. For some firms the sales of their products in China are higher than their sales in the US. US consumers benefit from low priced goods from China. The US uses China as its final assembly point for some of its products as well as employed Chinese inputs in its 
manufacturing firms based in the United Stated in order to reduce costs of production. China has the largest amount of US Treasury Securities at \$1.3 trillion as in May 2013. The purchase of US debt by China keeps US interest rates low (Morrison, 2011).

In accordance with (Petrović \& Gligorić, 2010), in Exchange Rate and Trade Balance: J-curve Effect, a deteriorating ex-change rate has a substantial impact on a nation's trade balance over time. In the short-run, while consumers are still trying to find cheaper substitute goods as the price of imports rises, the trade-balance actually worsens. However, in the long run, as consumers begin to find substitutes, the nation's trade balance will begin to improve.

According to (Antweiler, 2011), exchange rates in the short-run, are driven by the news and people's expectations. Therefore, there may be a significant lag between adjustments in the yuan-dollar exchange rate and shifts in either nation's price level. It means that there may be a delay between shifts in the exchange rate and shifts in the price of textile imports, implying that exchange rate shifts may not immediately affect import levels...

The US-China trade may have certain benefits, but it has also brought about tensions between the two countries. The US believes that the refusal of China to transit into a free market economy has affected trade between the two countries. China continues protecting its domestic industry through industrial government policies that make the domestic firms more competitive than the US firms. These policies include government financial support of government firms and imposing of trade and investment barriers for the US firms. This favors industries such as the Textile industry from the competition from foreign firms.

China does not adequately protect US Intellectual Property Rights (IPR's) and cyber espionage. For example, IPR infringement cost the US $\$ 48$ billion in 2008. As a member of the World Trade Organization (WTO), it often does not fully implement or meet its WTO obligations. China maintains a foreign exchange policy that limits the appreciation of the RMB to the dollar. These policies have harmed US textile firms and led to closures and job losses.

The US needs to become more forceful towards China than it is now for China's failure to meet WTO obligations. Member countries can present cases with WTO against other member countries that fail to meet WTO obligations. The US has a number of pending cases with WTO against China. The biggest concern for the US is confined to the rapid growth of its trade deficit with China.

Table 1. US trade deficit with China

\begin{tabular}{lc}
\hline Year & Amount in \$billions \\
\hline 1990 & 10 \\
2008 & 266 \\
2009 & 227 \\
2010 & 273 \\
2011 & 296 \\
2012 & 315 \\
2012 Projection & 324 \\
\hline
\end{tabular}

The solution to US-China trade issues is to make China take a leading role in international trade, which would lead to its economic rise. It should institute additional economic and trade reforms to continue the expansion of its economy. It can achieve this through appreciating its currency and boosting domestic spending.

\section{China's Currency Policy}

According to the US, the undervalued RMB is the cause of trade disputes between the two countries. China does not use a floating exchange rate policy but maintains a target exchange rate to the dollar. Between 1994 and 2005, China pegged the RMB to the US dollar at 8.28 per Yuan. Between July 2005 and July 2009, the RMB appreciated to the dollar by $21.1 \%$ to 6.83 . This appreciation was based on major foreign currencies including the dollar (Bergin \& Feenstra, 2009).

The target foreign exchange rate is set by imposing restrictions and controls over any capital transactions. This has led to China's large scale purchase of US dollars and dollar assets. During the global financial crisis of 2007-2008, the appreciations of the RMB stopped. In the period of 2009-2012, the foreign exchange rate of the RMB to the dollar remained at 6.83 as a measure to protect China from the low global demand for its products. 
Since June 2010 up to present, the RMB appreciated from 6.83 to 6.18 , which equals only $10.5 \%$. Since June 2012, the RMB has only appreciated by $2.1 \%$ (Jabara, 2009).

This is an indication that China still continues interfering with the RMB to maintain the exchange rate at a constant level to protect it from any decline in the demand for Chinese products. Another reason for this level of exchange rate is connected with the slowdown in China's accumulation of foreign exchange reserves in the past few years. The US textile industry continues suffering because of the undervaluation of the RMB against the dollar. The undervalued RMB is similar to a subsidy for Chinese exporters that make their goods cheaper in the US. At the same time, the undervaluation of the RMB makes US exports to China expensive. US textile firms cannot compete with Chinese firms due to them offering a low price, which leads to massive job losses in the US. The increase in Chinese exports to the US further increases the US China trade deficit, which causes high rates of unemployment (Morrison \& Labonte, 2011).

China's foreign exchange policy means that the country has a huge hold of US Treasury securities. This amount stands at \$1.3 trillion in 2013. Analysts argue that this huge amount may give China leverage over the US in relation to the US trade and foreign policy. China may make a decision to sell off US securities should the two countries have a dispute. Such a decision would lead to a sharp depreciation of global currencies such as the Euro. However, this is unlikely to happen since such a decision will harm both the US and China. As long as China decides to peg the RMB to the dollar, it must continue buying US securities to maintain the target rate (Morrison \& Labonte, 2008).

\section{US Textile Exports}

The US Textile industry is one of the industries affected by the exchange rate of the RMB to the dollar. The Chinese Textile industry has enormous strength in the global market. The US textile industry got protection under the Multi-Fiber Arrangement that imposed import quotas on Chinese textiles and clothing. Since the lapse of the arrangement in January 2005, Chinese textiles have rapidly grown causing market disruptions in the Textile industry. The lapse of the MFA greatly affected the US and Europe which led to the negotiation of new bilateral quotas with China that expired in 2008. China moved from being the 6th largest exporter of textiles in 2003 to being the largest exporter of textiles (Yu, 2012).

Textile exports in the brassiere category were at $\$ 120$ million in 2001 and grew to $\$ 474$ million in 2005. Total US textile imports from China were 48 billion in 2000 and increased to become $\$ 19$ billion in 2005. China's share of US textile imports grew from $11 \%$ to $25 \%$ in the same period of time. The US uses quotas to limit the amount of textile imports from China. For example, in the period between 2006 and 2008, the US and China agreed on quotas in 34 categories of textile products. The quotas require China to limit the annual growth rates of Chinese textiles into the United States. The quotas during the period between 2006 and 2008 were $8-10 \%$ in 2006, 10-15\% in 2007 and 15-17\% in 2008 (Schneider, 2011).

At the end of the MFA in 2005, Chinese textile exports grew quickly causing an immense impact on the US Domestic Textile industry. The prices of Chinese textile were cheaper than the US textiles because of the abundance of cheap labor in China. The US firms could not reduce their costs, which made their products expensive. This led to the shutdown of many US textile firms leading to huge job losses. The increase in Chinese textile exports also resulted in a huge trade imbalance between the US and China. China employs 1.9 million workers in the Textile and Clothing Industry compared to 700,000 workers for the US.

Between 2002 and 2004, before the lapse of the MFA, Chinese textile exports grew by an average of $22 \%$ annually. After the expiry of the MFA, Chinese textile exports grew by over $50 \%$. China's argument was that their textile export replaced exports from other US textile importers. However, the US textile producers still blamed China for their misfortunes. In order to appease the US, China voluntarily imposed a tax on all textile exports to the US, but this had very little effect.

According to WTO, if a member feels that imports from China are disrupting the market, the member can limit Chinese imports to a limit of $7.5 \%$ of annual growth for particular categories. This is the option European Union took between 2004 and 2005 with regard to certain textile categories from China. The US resorted to the same option with a similar agreement with China between 2006 and 2008 for 34 categories in textiles.

\section{China's Competitive Advantage}

China has an enormous competitive advantage over the US in the textile industry. The main reason for the competitive advantage is related to the undervalued RMB to the dollar. However, analysts show that this is not the only reason that allows China to enjoy a competitive advantage. There are other reasons that give China a huge competitive advantage in the textile industry. China's population is 1.3 billion which provides a massive 
domestic market and enables the country to enjoy economies of scale and economies of scope (Subramanian \& Wei, 2007).

The population provides abundant cheap labor for the textile firms. The US industry pays a textile worker $\$ 9.7$ an hour compared to China's labor cost of $\$ 0.88$ per hour. This is almost 11 times lower, which reduces costs for Chinese textile firms. This enables Chinese textile firms to charge low prices for their exports. For a comparison, the US workers have enhanced capital equipment and technology. However, their productivity is much lower than those of Chinese textile firms.

China has an easy access to raw materials, imports huge volumes of cotton and wool as well as enjoys huge domestic supplies of silk. The country has invested heavily in infrastructure which enables it to have fast delivery times. The argument that China has a huge competitive advantage in the textile industry because of the undervalued RMB may not be entirely true. This is because there are many other factors that give it a competitive advantage. The relationship between the RMB exchange rate and the US dollar and prices of US textile exports may not be as significant as they might seem.

\section{Statistical Analysis}

The relationship between RMB to the US dollar exchange rate and prices of US textile exports can be explained using data from the period 2001 to 2010. This will include data during the implementation of the MFA up to 2005 and data from the period after the MFA, which is after 2005. Data on the foreign exchange rates and textile imports from China were for the period 2000 to 2012. The data were taken from United States International Trade Commission, CEIC database and the National Bureau of Statistics of China (United States International Trade Commission, 2009).

The following information is the analysis of the data on the foreign exchange rates of RMB to the dollar from 2000 to 2012. The foreign exchange rate data show a mean of 7.6208 and a standard deviation of 0.77866 . The exchange rate of the RMB to the dollar was constant from 2000 to 2005 . The RMB appreciated from 2005 to 2009 to a level of 6.83 RMB to the dollar. It remained at 6.83 during the period between 2009 and 2010 as China needed to limit the impact of the global financial crisis that led to a decline in the demand for Chinese products. Since 2012, the RMB has appreciated slightly to 6.18 to the dollar. According to the economic theory, a change in the exchange rate of the RMB to the dollar will increase or decrease the cost of Chinese goods with regard to the US. An increase in the cost of Chinese textiles will decrease the demand for Chinese textiles in the US. The US consumers will prefer to buy US textiles because the Chinese textile will become expensive RMB Appreciation against the dollar 2000-2012.

Table 2. RMB appreciation against the dollar 2000-2012

\begin{tabular}{llllll}
\hline \multicolumn{5}{c}{ Descriptive Statistics } \\
\hline & $\mathrm{N}$ & Minimum & Maximum & Mean & Std. Deviation \\
\hline Exchange Rate & 13 & 6.18 & 8.28 & 7.628 & .77866 \\
Valid N (listwise) & 13 & & & & \\
\hline
\end{tabular}

The following is the analysis of American imports from China to the US during the period between 2002 and 2010. The American imports data show a mean of 59.875 billion and a standard deviation of 25.244.

Table 3. American imports from China 2002-2010

\begin{tabular}{llllll}
\hline \multicolumn{5}{c}{ Descriptive Statistics } \\
\hline & $\mathrm{N}$ & Minimum & Maximum & Mean & Std. Deviation \\
\hline American Imports & 8 & 25.00 & 92.00 & 59.8750 & 25.24416 \\
Valid N (listwise) & 8 & & & & \\
\hline
\end{tabular}

The undervaluation of RMB to the US dollar has increased the US trade deficit with China. 
Table 4. US Trade with China 1980-2013 (\$ billions)

\begin{tabular}{cccc}
\hline Year & US Exports & US Imports & US Trade Balance \\
\hline 1980 & 3.8 & 1.1 & 2.7 \\
1985 & 3.9 & 3.9 & -10.4 \\
1990 & 4.8 & 15.2 & -33.8 \\
1995 & 11.7 & 45.6 & -83.8 \\
2000 & 16.3 & 100.1 & -201.6 \\
2005 & 41.8 & 243.5 & -232.5 \\
2006 & 55.2 & 287.8 & -256.3 \\
2007 & 65.2 & 321.5 & -266.3 \\
2008 & 71.5 & 337.8 & -226.8 \\
2009 & 69.6 & 296.4 & -273.1 \\
2010 & 91.9 & 364.9 & -295.5 \\
2011 & 103.9 & 393.3 & -315.0 \\
2012 & 110.6 & 425.6 & -324.2 \\
\hline
\end{tabular}

Source: Census Bureau of Statistics, 2013.

\subsection{Analysis of US Exports to China}

The analysis of US exports to China shows a mean of 54.62 billion and a standard deviation of 41.40179.

Table 5. US exports to China 1980-2013

\begin{tabular}{llllll}
\hline \multicolumn{5}{c}{ Descriptive Statistics } \\
\hline & $\mathrm{N}$ & Minimum & Maximum & Mean & Std. Deviation \\
\hline US Exports & 14 & 3.80 & 114.60 & 54.6286 & 41.40179 \\
Valid N (listwise) & 14 & & & & \\
\hline
\end{tabular}

\subsection{Analysis of US Imports from China 1980-2013}

The analysis of US imports from China shows a mean of \$ 233.9643 billion and a standard deviation of 165.241 .

Table 6. US imports from China 1980-2013

\begin{tabular}{lrrrrc}
\hline \multicolumn{5}{c}{ Descriptive Statistics } \\
\hline & $\mathrm{N}$ & Minimum & Maximum & Mean & Std. Deviation \\
\hline US Imports & 14 & 1.10 & 438.80 & 233.9643 & 165.24100 \\
$\begin{array}{l}\text { Valid N } \\
\text { (listwise) }\end{array}$ & 14 & & & & \\
\hline
\end{tabular}

\subsection{Analysis of US-China Trade Balance}

The analysis of US-China trade balance shows a mean of -179.7571 and a standard deviation of 125.53897.

Table 7. US China trade balance 1980-2013

\begin{tabular}{|c|c|c|c|c|c|}
\hline \multicolumn{5}{|c|}{ Descriptive Statistics } & \multirow[b]{2}{*}{ Std. Deviation } \\
\hline & $\mathrm{N}$ & Minimum & Maximum & Mean & \\
\hline US Trade Balance & 14 & -324.20 & 2.70 & -179.7571 & 125.53897 \\
\hline Valid N (listwise) & 14 & & & & \\
\hline
\end{tabular}


The US would like the RMB to appreciate as this would increase the global demand for Chinese products as well as increase the value of RMB. A rise in the price for Chinese products will lead to a reduction in Chinese exports to the US, and this will reduce the US-China trade imbalance.

\section{Conclusion}

The relationship between RMB to US exchange rate and the prices of US textile exports from China is not significant. The US blames China's foreign exchange policy on the RMB to the dollar as unfair to its industries; especially as far as the textile one is concerned. The undervaluation of the RMB to the dollar makes Chinese textile exports to the US cheaper than US textiles in the domestic market. This has led to the shutdown of US textile firms leading to job losses. Analysts argue that China has a competitive advantage in the textile industry due to other reasons rather than the undervaluation of RMB. China has an abundant supply of cheap labor given that the textile industry is labor intensive and does not require technology. China has a population of 1.3 billion that enables it to use economies of scope and scale. China has also invested heavily in infrastructure that reduces delivery times.

The US should consider innovative solutions to reduce its trade balance with China. The US should look for solutions that will make it more competitive than China in the textile industry. The focus should not be on asking China to appreciate the value of RMB. The US textile industry should resort to innovative ways to use the latest fabrics and new stitching methods. It should review its textile product range and produce textile that are not price sensitive. What is more, the country should employ new marketing methods such as distribution through the Internet. It should not rely on safeguarding measures through the WTO but look for ways to be as competitive as China in the textile industry. The appreciation of the RMB will reduce US textile imports from China.

\section{References}

Antweiler, W. (2011). Purchasing power parity. University of British Columbia.

Bergin, P. R., \& Feenstra, R. C. (2009). Pass-Through of Exchange Rates and Competition between Floaters and Fixers. Journal of Money, Credit and Banking, 41(s1), 35-70. http://dx.doi.org/10.1111/j.1538-4616.2008.00198.x

Jabara, C. L. (2009). How Do Exchange Rates Affect Import Prices? Recent Economic Literature and Data Analysis. US International Trade Commission, Office of Industries Working Paper no. ID-21 (revised).

Krugman, P. R. (2008). International Economics: Theory And Policy, 8/E. Pearson Education India.

Morrison, W. M. (2011). China-US trade issues.

Morrison, W. M., \& Labonte, M. (2008). China's holdings of US securities: implications for the US Economy.

Morrison, W. M., \& Labonte, M. (2011). China's Currency Policy: An Analysis of the Economic Issues. Congressional Research Service.

Petrović, P., \& Gligorić, M. (2010). Exchange rate and trade balance: J-curve effect. Panoeconomicus, 57(1), 23-41. http://dx.doi.org/10.2298/PAN1001023P

Schneider, F. (2011). The Effect of China's Exchange Rate Policy on US Textile Imports. Editorial Objective, $1001,109$.

Subramanian, A., \& Wei, S. J. (2007). The WTO promotes trade, strongly but unevenly. Journal of International Economics, 72(1), 151-175. http://dx.doi.org/10.1016/j.jinteco.2006.07.007

United States International Trade Commission. (2009). Textile and Apparel Imports from China, Statistical Reports. United States International Trade Commission.

Yu, M. (2012). Does Appreciation of the Renminbi Decrease Imports to the United States from China? Contemporary Economic Policy, 30(4), 533-547. http://dx.doi.org/10.1111/j.1465-7287.2011.00260.x

\section{Copyrights}

Copyright for this article is retained by the author(s), with first publication rights granted to the journal.

This is an open-access article distributed under the terms and conditions of the Creative Commons Attribution license (http://creativecommons.org/licenses/by/3.0/). 